\title{
An investigation into English Language Teaching Textbooks Used at Medical Sciences Universities: Implications for Educational Justice
}

\section{Iman Alizadeh1* \& Fatemeh Shafaee2}

\section{* Correspondence: \\ Iman_alizadeh96@gums.ac.ir \\ 1. English Language Department, School of Nursing, Midwifery and Paramedical Sciences, Guilan University of Medical Sciences, Rasht, Iran \\ 2. Anesthesia Department, School of Nursing, Midwifery and Paramedical Sciences, Guilan University of Medical Sciences, Rasht, Iran}

Received: 18 December 2020

Revision: 19 February 2021

Accepted: 24 February 2021

Published online: 20 March 2021

\begin{abstract}
General English (GE) is a course offered in all education programs by the Iranian medical education system. However, no curriculum has been developed for the course and teachers develop their syllabus, which largely relies on textbooks. This study aimed to investigate what textbooks used for teaching GE at the Iranian medical sciences universities and what language skills are covered in the textbooks. To this end, six medical universities were targeted and the textbooks used by them were collected and analyzed. The results showed that the textbooks used in the universities differed in terms of number (one or many) and type (medical, non-medical, and a combination of them). Certain textbooks were used commonly in most universities. The textbooks also covered the language skills differentially with vocabulary and reading being the most popular and listening and pronunciation being the least popular ones. The study concludes that there is no harmony in the GE textbooks in the universities, which results from the lack of a unified national curriculum. The study argues that differences in the textbooks can adversely affect the quality of education and educational justice and has implications for organizing English language teaching at medical universities.
\end{abstract}

Keywords: English language, educational justice, textbooks, medical universities 


\section{Introduction}

General English (GE) has been included in the curriculum of all educational programs offered in the Iranian medical education system. At the university level, English is a required language subject offered as a three-credit course in the freshman and sophomore years. After passing the general English course, students continue to take English for Specific Purposes (ESP) courses. However, despite almost all other courses, no single syllabus has been developed for the GE by educational policymakers at the Iranian ministry of health, treatment, and medical education. Therefore, English teachers themselves develop a syllabus, which largely relies on the textbook they opt for. Therefore, the textbook to a large extent determines the education the students receive in the GE courses and have an influence on educational justice.

Educational justice means providing equal educational opportunities for students and includes implementing uniform educational rules for all individuals, and providing the grounds for acquiring skills and preparation for the labor market (Rahmanian, Hosseini, \& Haghbeen, 2017). Therefore, GE textbooks and materials play an important role in implementing justice and improving the English proficiency of medical sciences students. A textbook is one of the most important learning resources in educational systems and is the main material of the curriculum (Nejati, Cheraghi, \& Nasery, 2018). According to Jalali (2011), many institutions develop their syllabus based on a course book. The choice of resources has a major impact on what happens in the course as well (Ebadi \& Naderifarjad, 2015).

According to Sahragard and Rahimi (2018), English textbook has an important relationship with the learning of the students. Therefore, the use of efficient and reliable resources in the field of education, especially at the level of higher education due to the direct impact of these resources on the scientific performance of students is an important and considerable matter. Therefore, textbook research is essential as it is effective in designing appropriate learning opportunities for students. Sahragard and Rahimi (2018) emphasize the role of textbooks in English teaching, adding, "The evaluation of the textbooks for English has a significant role in the future success of the educational program." Additionally, evaluation in the educational context has been defined as an activity to collect information to make an educated decision (Genesee \& Upshur, 1996).

Evaluation of educational resources including textbooks is an educational need as it can determine how a textbook can be promoted or judged fairly (Sahragard \& Rahimi, 2018). Educational materials such as textbooks should be evaluated based on students' needs (Akbari \& Pourabbas, 2015). Evaluating textbooks can reveal the connection between learning problems and the curriculum, and contribute to the incorporation of the objectives of the curriculum in the textbooks properly (Al Harbi, 2017). Evaluating educational resources and discovering the problems in the textbooks can also lead to the production of new books (The fundamental reform document of education, 2011). The fundamental reform document of education (2011) also emphasizes that curricula and their content should be carefully reviewed to identify and correct irrelevant and inappropriate contents. Textbook research is essential as it is effective in designing appropriate learning opportunities for students (Al Harbi, 2017).

Because of the significant role of English in medical sciences, a three-credit general English course is offered at the Iranian medical sciences universities. The importance of English in the medical professions is that scientific, technological, and academic information is presented in English (Crawford \& Candlin, 2013). Therefore, learning and improving English language skills can be highly instrumental for students of medical sciences (Milosavljević, 2008, Milosavljević \& Bakić, 2008). Resources used for general English and English for specific purposes courses are among the most critical components of the education system (Ebadi \& Naderifarjad, 2015). Research has shown that English textbooks can affect the way teachers teach and students learn English (Ahmadi \& Derakhshan, 2016). Since textbooks are the resources from which students receive most of the language information they need (Richards, 2001), these resources need to be reviewed and evaluated in terms of content. The evaluation of a textbook is possible through conducting a comprehensive examination of the book in terms of its content and objectives (Nili Ahmad Abadi \& Dana, 2017).

\subsection{Statement of the Problem}

The body of literature on textbook evaluation shows that insufficient studies have been conducted on materials used for teaching English at medical universities. The present study aimed to identify general English language teaching resources in Guilan, Mazandaran, Babol, Golestan, Semnan, and Shahroud universities of medical sciences. Moreover, despite the significance of the general English course in medical universities, the Iranina Ministry of Health Treatment and Medical Education does not provide a specific curriculum for the course and different universities use different 
resources to teach English. Leaving the choice of textbooks to the universities can be to the detriment of students and seems to be against educational justice. As students of the same field in different medical universities take the same English language tests to continue their education at a higher level, they are expected to benefit from the same educational resources. This study aimed to identify the general English textbooks used in the medical sciences universities and to examine the resources in terms of content. Moreover, it intended to examine the textbook in terms of similarities and differences in the incorporation of language skills. By identifying the general English textbooks in the universities and determining the objectives included in each of these books, a more coherent program can be provided to teach English at medical universities to meet the current and future needs of the students. Additionally, the development of a more coherent general English program will contribute to educational justice.

\subsection{Research Questions}

The present study aimed to investigate the textbooks used for teaching general English at the Iranian medical sciences universities and the language skills covered in the textbooks. The objectives of the present study urged the researchers to formulate the following research questions:

Question 1: What textbooks are used for teaching general English at the Iranian medical sciences universities?

Question 2: What language skills are covered in the textbooks used for teaching general English at the Iranian medical sciences universities?

\section{Review of the Literature}

Numerous studies have been conducted on the evaluation of education programs and materials particularly in the field of English language teaching. These studies have compared the existing teaching resources which have been mainly developed to be used at a single university from the perspective of students and teachers (Karami \& Lohran Poor, 2020; Maleki \& Kazemi, 2012; Saharkhiz Arabani, Fathi, \& Balalaei Somehsaraei, 2019). Maleki and Kazemi (2012), for instance, compared Medical Terminology (MT) (Cohen, 2008) and English for the Students of Medicine (II) (Tahririan \& Mehrabi, 1994), which are used as English language resources at some medical universities. They aimed to examine which of these books meets the expectations of professors and students and discover the strengths and weaknesses of these books. The results indicated that from both teacher's and students' perspectives, MT was significantly better than ESM in terms of layout and design, activities, language type, topics, and content (Maleki \& Kazemi, 2012). The study, however, did not deal with the incorporation of different language skills in the two books.

Similarly, Ebadi and Naderifarjad (2015) compared Oxford English for Careers and medicine English for medical students published by the Organization for Researching and Composing University textbooks in the Humanities (SAMT) based on students' viewpoints in terms of theoretical consideration, the organizational features, and practical considerations, the content, the language skill, the vocabulary, the grammatical structure. Results indicated that Oxford English for Careers: medicine appealed to the majority of the students. Findings also indicated that, regarding theoretical considerations, the students who had covered the SAMT textbook were significantly less satisfied with their textbook than the participants who had covered the other book. They conclude that the book published by Oxford is more appealing to the students (Ebadi \& Naderifarjad, 2015). This study also did not deal with the incorporation of different language skills in the two textbooks. The interesting point, however, was that both books are used in many Iranian medical universities.

Razmjoo and Raissi (2010) investigated whether textbooks designed for the students of medical sciences were appropriate in terms of the theoretical considerations, the organizational features and practical considerations, the content, the language skills, the vocabulary and the grammatical structure from the instructors' and students' viewpoints, what the students' and instructors' overall impression of the textbooks was, and if there was any significant difference among the students' and instructors' viewpoints. They evaluated as many as nine books used in medical universities. The results of their study showed that the instructors were not satisfied with the organizational features and practical considerations of the ESP Medicine textbooks, but the students found them satisfactory. The content of the textbooks was not found to be satisfactory by both the instructors and students. The instructors were not satisfied with the textbooks in terms of the skills, but it was not the case for students. The instructors were satisfied with the ESP Medicine textbooks in terms of vocabulary, but the students were not. The structure of the ESP Medicine books was satisfactory for the instructors, but not for the students. Both the instructors and students were not satisfied with the content of the textbooks (Razmjoo \& Raissi, 2010). 
DehGhaedi (2013) also compared GE reading textbooks used in universities in Iran in terms of their vocabulary size, vocabulary levels, and text overage. The textbooks they collected were Reading Challenge, Access Reading 3, Active Skills for Reading 3, Concepts \& Comments, Select Readings (intermediate), and Select Readings (upperintermediate). It was found that Active Skills for Reading 3 and Select Readings (upper-intermediate) fitted the requirements of students at the upper intermediate level of language proficiency, Select Readings (intermediate) and Concepts \& Comments were appropriate for intermediate level students, and Reading Challenge and Access Reading 3 were suitable for low-level students.

Pournia (2019) also compared textbooks used in the Iranian medical universities in terms of their lexical coverage. He aimed to investigate the lexical characteristics in the English language references and tests of the Comprehensive Examination of Basic Medical Sciences (CEBMS). The textbooks he targeted were English for Medicine in Higher Education Studies by (Fitzgerald, McCullagh, \& Wright, 2010), Professional English in Use: Medicine (Glendinning \& Howard, 2007), Medical English (Voughan, 1989), English for the Students of Medicine (Tahririan \& AmeriGolestan, 2011), and Medical Terminology: An Illustrated Guide (Cohen \& Depetris, 2013). To do so, the texts of the textbooks were analyzed for lexical coverage, vocabulary size, and vocabulary level. Furthermore, the lexical coverage of five CEBMS English language tests in the references was surveyed. The results of the study showed that the English language references of the CEBMS do not satisfy medical students' needs including passing the English language test of the CEBMS and comprehending medical texts in English. The study recommends that more English language references with higher lexical characteristics should be introduced by the Iranian Ministry of Health or at least by the relevant instructor (Pournia, 2019).

Shomoossi, Rad, and Rakhshani (2013) also researched the views of nurses and students of nursing on the efficacy of English programs at Iranian medical universities. They note that the general English courses encourage the students to focus on reading comprehension, literal translation, lexical equivalence, and simple exercises in English, concluding that the courses offered at the university level do not match with the future professional requirements of the practitioners (Shomoossi et al., 2013). As the studies by Pournia (2019) and Shomoossi et al. (2013) showed English language teaching at medical universities in the Iranian context suffer a lack of appropriate methodology and references, which can negatively affect the quality of education the students receive and hence educational justice. The lack of a curriculum identifying the textbooks which can be used in the general English courses, which can contribute to the success of the program (Norouzzadeh \& Kossary, 2010), can be another factor threatening educational justice in teaching English at medical universities.

According to Slattery (2006), having a curriculum will lead to justice and can help all students have access to the same teaching materials. Similarly, Shomoossi et al. (2013) complain about the lack of harmony in teaching English at medical universities, explaining, "In the market, the course books are diverse, and instructors are not normally given clear instructions and training on methods of teaching and lesson plans." Pournia (2019) also reports that the general English resources medical sciences students study cannot satisfy Iranian medical students' needs. He adds that to the students' needs, more English language references with higher lexical characteristics should be introduced by the Iranian Ministry of Health.

From the review of the literature on the evaluation of materials used in medical universities, it can be said that researchers have mainly evaluated textbooks developed and prescribed by SAMT. They have also compared books used at the same university. There seems to be a gap in the literature on the textbooks different medical universities across the country use and their coverage of language skills. Medical universities in the Iranian context are not obliged to use the books produced by SAMT. Therefore, they may opt for other materials. None of the studies have surveyed the English textbooks the English teachers at medical universities use to teach general English. Additionally, none of the studies in this area have investigated the incorporation of different language skills in the textbooks used at medical universities. The present study aimed to bridge the existing gaps by identifying the general English textbooks used at six medical sciences universities and examining these resources in terms of content. Moreover, it intended to investigate similarities and differences among the textbooks in terms of language skills.

\section{Methodology}

\subsection{Design of the Study}

The research questions and objectives of the study determine the design of a study. As the present study aimed to investigate what textbooks used for teaching general English at the Iranian medical sciences universities and what 
language skills are covered in the textbooks, it used a descriptive research design. A descriptive research design provides an accurate description of an event or situation. The data-collection methods which are used in this design involve the use of focus groups and document review. The descriptive design targets the details of what, where, when, and why of a situation or an event (Bradshaw, Atkinson, \& Doody, 2017).

\subsection{Raters}

There were two raters in the present study. The first rater was male and aged 39 years. He was at an advanced level of English proficiency and had 20 years of experience in teaching English. The second rater of the study was female and aged 24 years. She was at an advanced level of English proficiency. The raters were informed that participation in the study was voluntary and they can withdraw from the study when they wish to do so.

\subsection{Materials}

The materials used in this study were the textbooks used as teaching resources for the general English course at six Iranian medical sciences universities of Guilan, Mazandaran, Babol, Golestan, Shahroud, and Semnan.

\subsection{Instruments}

After collecting all the required resources, the content analysis phase of the textbooks began. For this purpose, a researcher-made checklist was used. This checklist consisted of three parts: 1) the names of universities, 2) the name of the textbooks used in the universities, and 3) the language skills covered in the textbooks. The name of the universities (Guilan, Golestan, Mazandaran, Babol, Shahroud, and Semnan) entered in the first part. The language skills part was divided into reading, writing, speaking, listening, vocabulary, grammar, and pronunciation skills. Before using the checklist, it was piloted by two other raters. They suggested some modifications. The modifications the raters had asked for were implemented. The validity of the checklist was confirmed by three experts in the field of language teaching and the inter-rater reliability of the checklist showed a high degree of agreement between the two raters.

\subsection{Data Collection and Analysis}

The data collection phase of the study began with the collection of the general English books used at the six medical sciences universities. To do so, in the first step, the researchers search for the general English language lesson plan on the website of the universities. The search, however, showed that most of the universities have not posted the resources on their website or if they have done the resources are either missing or incomplete. Next, the Vice-Chancellor for the education of Guilan University of Medical Sciences entered into a formal correspondence with the Vice-Chancellor for the education of the six universities, asking for the resources used in the general English courses. Each of the six universities, then, sent a list of resources they used in the general English course to Guilan University of Medical Sciences in a formal letter. To analyze the data, the two raters reviewed the collected books separately. The raters were asked to review and analyze the books in terms of the skills covered in them. They were also asked to study the table of contents and introduction part of the books and pay attention to the teaching goals mentioned in the books. They were also asked to analyze the content of the books and discover the language skills emphasized in different sections of each unit of the books. They were told to indicate their evaluation by marking their choices with a cross on the checklist.

\section{Results}

One of the objectives of the study was to identify the English language teaching textbooks used at the medical universities in the Iranian context. The textbooks used by professors in the general English course are presented in Table 1 below. 
Table 1. The textbooks used in the general English course at six medical universities

\begin{tabular}{|c|c|}
\hline Universities & Textbooks \\
\hline \multirow{3}{*}{$\begin{array}{l}\text { Guilan University of } \\
\text { Sciences }\end{array}$} & 1. English for the students of medicine (Deedari \& Zia-Hossaini) \\
\hline & $\begin{array}{l}\text { 2. English for the students of medicine (Atai, shoja, Kafshgarsouteh, } \\
\text { Zolghadri) }\end{array}$ \\
\hline & 3. Destination B2 \\
\hline \multirow{9}{*}{$\begin{array}{l}\text { Babol University of Medical } \\
\text { Sciences }\end{array}$} & 1. English for medical purposes: Doctors (Alum, 2012) \\
\hline & $\begin{array}{l}\text { 2. Medical English clear \& simple: A practice-based approach to English for } \\
\text { ESL healthcare professionals (Hull, 2009) }\end{array}$ \\
\hline & $\begin{array}{l}\text { 3. Good practice: communication skills in English for medical practitioners } \\
\text { (McCullagh \& Wright, 2008) }\end{array}$ \\
\hline & 4. Professional English in use: medicine (Glendenning \& Howard, 2007) \\
\hline & 5. Collocations in use (McCarthy \& O’Dell, 2005) \\
\hline & $\begin{array}{l}\text { 6. English in medicine: A course in communication skills (Glendenning \& } \\
\text { Holmstrom, 2005) }\end{array}$ \\
\hline & 7. Medical English (Ribes \& Ros, 2005) \\
\hline & 8. English for doctors (Maria Gyorffy, 2005) \\
\hline & 9. English for the students of medicine I (Didari \& Zia-Hosseni, 1391) \\
\hline
\end{tabular}

\begin{tabular}{|c|c|c|}
\hline \multirow{3}{*}{$\begin{array}{l}\text { Mazandaran } \\
\text { University of } \\
\text { Medical Sciences }\end{array}$} & $\begin{array}{l}\text { School of } \\
\text { Pharmacy }\end{array}$ & Intermediate-select readings \\
\hline & $\begin{array}{l}\text { Paramedical } \\
\text { Sciences }\end{array}$ & $\begin{array}{l}\text { 1. Concepts and comments (Patricia Ackert) } \\
\text { 2. General English (Hossein Farhady) }\end{array}$ \\
\hline & Nursing & $\begin{array}{l}\text { 1. Reading through interaction second edition (Seyyed Akbar Mirhassani \& } \\
\text { Hossein Farhady) }\end{array}$ \\
\hline
\end{tabular}

2. Cover to cover: reading comprehension and fluency (Day, Yamanaka, Harsch, \& Ono)

3. Inside reading: The academic word list in context (Lawrence J.Zwier)

\begin{tabular}{ll}
\hline $\begin{array}{l}\text { Golestan University of Medical } \\
\text { sciences }\end{array}$ & 1. Reading through interaction (Hossein Farhady \& Seyyed Akbar Mirhassani) \\
& 2. Interchange (Jack C. Richards)
\end{tabular}

$\begin{array}{ll}\text { Semnan University of Medical } & \text { 1. English for the students of medicine } \\ \text { Sciences } & \text { 2. professional English in use: medicine } \\ & \text { 3. Tune in(2) }\end{array}$

Shahroud University of Medical English for the students of medicine Sciences

The table shows that the universities differed in the number of textbooks they used. For example, Shahroud University of Medical Sciences used only one textbook, while Babol University of Medical Sciences used as many as nine textbooks. Moreover, the universities differed in the type of textbooks they used. Babol University of Medical Sciences, for example, used medically oriented general English textbooks, whereas Golestan University of Medical 
Sciences employed non-medically oriented general English textbooks; other universities also used a combination of medically and non-medically oriented textbooks.

Table 2. The frequency of the textbooks in medical universities

\begin{tabular}{lll}
\hline Universities & Frequency & Textbooks \\
\hline Guilan University of Medical Sciences & & $\begin{array}{l}\text { English for the Students of Medicine } \\
\text { (Deedari \& Zia Hossini) }\end{array}$ \\
$\begin{array}{l}\text { Semnan University of Medical Sciences } \\
\text { Babol University of Medical sciences }\end{array}$ & & \\
Shahroud University of Medical Sciences & & \\
\hline $\begin{array}{l}\text { Golestan University of Medical Sciences } \\
\text { Mazandaran University of Medical }\end{array}$ & $r$ & Reading through Interaction \\
Sciences & & (Hossein farhady \& Seyyed Akbar Mirhassani) \\
\hline $\begin{array}{l}\text { Semnan University of Medical Sciences } \\
\text { Babol University of Medical Sciences }\end{array}$ & $r$ & Professional English in Use: Medicine \\
\hline
\end{tabular}

From the table, the universities can be categorized into three groups. The table shows that four of the six universities used a book, while two other universities used another book. It was also noticed that one of the universities in the first group and one in the second group used a similar book.

Table 3. The incorporation of language skills in the frequently used textbooks

\begin{tabular}{|c|c|c|c|c|c|c|c|c|}
\hline \multirow[t]{2}{*}{ Textbooks } & \multicolumn{8}{|c|}{ Language skills } \\
\hline & Reading & Writing & Listening & Speaking & Grammar & Vocab & Translation & Pronunciation \\
\hline $\begin{array}{l}\text { English for } \\
\text { the Students } \\
\text { of Medicine } \\
\text { (I) }\end{array}$ & $x$ & $x$ & $x$ & $x$ & $x$ & & & $x$ \\
\hline $\begin{array}{l}\text { Reading } \\
\text { through } \\
\text { Interaction } \\
3\end{array}$ & & & $x$ & & $x$ & & & $x$ \\
\hline $\begin{array}{l}\text { Professional } \\
\text { English in } \\
\text { Use: } \\
\text { Medicine }\end{array}$ & & & $x$ & & & & $x$ & \\
\hline
\end{tabular}

As the table shows, none of the textbooks incorporated all of the language skills. The vocabulary skill was the language sub-skill which was covered in all the three frequently used books; listening was not covered in any of the textbooks. Reading and speaking were covered in three of them. Grammar, translation, and pronunciation were also covered only in one of them. 


\subsection{Description of the Three Frequently Used Textbooks}

Book 1: English for the Students of Medicine

This book has been organized and designed in 19 units. Each unit of the book consists of three sections, namely section one, section two, and section three. Section one, which has been designated as pre-reading, consists of a list of vocabulary which is used in the reading passage, explanation about the vocabularies, and grammatical points. Section two, which has been called reading, is composed of a reading passage and exercises about the passage. In each unit, there are two reading passages; one is in section two and one is in section three. Section three, which is also called the homework section, contains exercises on vocabularies, grammar exercises, a second reading passage, and translation tasks. Below, each of the language skills in the three sections is briefly described. In this book, there are two reading passages in each unit. The reading passages are exclusively on the issues about medical sciences. Such reading topics as The common cold, a balanced diet, Defense against disease, Defense and immunity, Germs, infection and disease, the world of microbes are incorporated in the book.

The reading passages are at upper-intermediate and advanced levels and are at least 700 words. The reading passages are merely textual and do not have any images or audio files. After the reading passage, come relevant questions in the form of true or false, multiple-choice items, oral questions. The speaking skill has been narrowly dealt with in the book. There is no section in the book providing the students with techniques or teaching materials on the speaking skill. At the end of the first reading compression passage, a number of questions are asked by the students. The students are asked to answer the questions orally based on the information in the reading passage. In each unit of the book, there is a section for presenting grammatical points and relevant exercises. Each unit of the book begins with a list of words.

The definitions of the words are given in English. An example in which the target word is used is also given. There is no audio for the pronunciation of the words; the phonetic of the words, however, is given. To work on the students' vocabulary knowledge, different types of exercises including fill in the blanks, matching, multiple-choice questions, parts of speech are incorporated in the book. At the end of each unit, there is also a decontextualized list of medical words in English; the students are asked to write the Persian equivalent of the words. At the beginning of each unit, there is a list of vocabulary. The pronunciation of the words is given in phonetics. The last passage of each unit is an English text for translation; the students are asked to translate the passage from English into Persian. There is no section providing students with translation techniques or even tips. The translation passages are medical texts and are normally at an upper-intermediate to advanced level of difficulty. The writing skill and listening skill have not been incorporated into the book.

\section{Book 2: Reading through Interaction 3}

This book contains 14 units and each unit commences with a preamble containing information on the content of the unit. Each unit has three sections of reading, speaking, and vocabulary. At the end of some of the units, a part called the focus on test has been devised concentrating on multiple-choice questions of reading comprehension or vocabulary. Each unit of the book has three passages on different issues that are often irrelevant to the concepts of health and medicine. Such reading topics as How to read faster, Mark Twain, how to take tests, eat like a peasant feel like a king, thou shalt not smoke, the cruel winds, first-time tourists need a pocket guide to downtown internet, laser: support of our time, privacy losses to computers, and New York botanist wins Nobel medical prize are contained in the book. Of the three passages incorporated in the reading section, the first and second passages are normally long, and the third one is short passages extract from magazines or brochures, etc.

There is no audio file for the passages and their difficulty level is not shown. Each of the passages had a before-youread section which requires students to answer some questions related to the upcoming reading passage. After each passage, there are various types of exercises including multiple-choice items, true or false items. The student is asked to study the passage and answer the questions. The speaking section in the books is in the form of answering some oral questions. They are not dialogic or conversational. They require the students to answer the questions after studying the reading comprehension passage in the book. There is a part on vocabulary in the book. In this section, a text is given and some words in the text are targeted in the form of multiple-choice items and fill-in blanks items. There is no section on grammar, pronunciation, writing, listening, or translation in this book. 


\section{Book 3: Professional English in Use: Medicine}

The book contains as many as 60 units all dealing with medical issues. The book contains such topics as health and illness, Parts of the body, Functions of the body, Medical practitioners, Nurses, Allied health professionals, Hospitals, Primary care, Medical education, The overseas doctor, Symptoms and signs, Blood, Bones, Childhood, The endocrine system, The eye, The gastrointestinal system, Gynecology, The heart and circulation, infections, Mental illness, The nervous system, Oncology, and pregnancy and childbirth. The main focus of the book is on vocabulary. To begin with, the book presents the new vocabularies and expressions in each of the units using tables, graphs, images, and texts. Next are the exercises which come in a variety of forms including fill in the blanks, matching items, ordering sentences, solving a puzzle, interpreting reports, and medical tests, etc. In some units, the students are asked to write a short note using the new words they have learned. There is no section in the book on reading, speaking, listening, pronunciation, grammar, translation, etc.

\section{Discussion}

The primary purpose of the study was to discover the GE textbooks used in the medical universities of Guilan, Golestan, Mazandaran, Babol, Shahroud, and Semnan. The findings showed that different universities used different textbooks in the GE courses. A number of the textbooks, however, were used similarly in the universities. English for the students of medicine by Deedari \& Zia Hossini (Deedari \& Zia Hosseini, 1997), for example, were used in Guilan, Babol, Shahroud, and Semnan Universities of Medical Sciences and Reading through Interaction by Hossein Farhady \& Seyyed Akbar Mirhassani (Mirhassani \& Farhadi, 1382) was used at Golestan and Mazandaran Universities of Medical Sciences. Professional English in Use: Medicine by Glendenning \& Howard (Glendinning \& Howard, 2007) was used at Semnan and Babol Universities of Medical Sciences. Therefore, each of the universities used one or two books independently, and one or two books similarly.

The interesting point was that in Mazandaran University of Medical Sciences, different colleges used different textbooks. The differences in the textbooks used at the universities affiliated with the same ministry could be due to a lack of a unified curriculum of teaching English. Despite all other programs for which a curriculum has been developed by the vice-chancellery for the education of the Iranian ministry of medical health, treatment and education, teaching general English has been left without a curriculum and universities offer this course based on their own resources and facilities. Despite the significance attached to learning English in medical sciences, the lack of curriculum for teaching the course proves a huge gap in the medical education system. Scholar in the field has compared the need for curriculum in an educational program to the plan of a building, describing it as one of the pivotal components of a program contributing to the success of the program (Norouzzadeh \& Kossary, 2010).

According to Slattery (2006), curriculum has become "a search for a deeper understanding that will lead to justice, compassion, and ecologically sustainability where the boundaries between the center and the margin are blurred, and all students have access to the text" (p. 281). According to the definition, the existence of a curriculum can guarantee that students in all universities receive the same level of information from similar textbooks. Furthermore, GE is one the most important subjects of the Comprehensive Examination of Basic Medical Sciences (CEBMS), the students of the medical sciences in the Iranian context should sit for to pursue their education at higher levels. It seems that the lack of harmony in the materials students at different universities study contradicts with the notion of justice raised by Slattery (2006). Therefore, the development of a curriculum can largely contribute to the enactment of education justice in teaching GE in medical education universities.

Another significant finding of the study was that the different textbooks used by medical universities do not seem to meet the medical sciences students' needs. For example, Professional English in Use: Medicine (Glendinning \& Howard, 2007), and English for the Students of Medicine (Deedari \& Zia Hosseini, 1997) were two books commonly used in the medical sciences universities. Research, however, has found that the books are lacking in the qualifications in many aspects. Pouria (2019) evaluated the texts of Professional English in Use: Medicine and English for the Students of Medicine for lexical coverage, vocabulary size, and vocabulary level. He reported that the English language references do not satisfy medical students' needs including passing the English language test of the CEBMS and comprehending medical texts in English. Moreover, researchers who have compared English for the Students of Medicine, the book used in four out of five universities investigated in the current research, with other textbooks, have reported that the book fails to reach the standards of other books published by publications like Oxford (Ebadi \& Naderifarjad, 2015; Maleki \& Kazemi, 2012). 
Tajeddin (2005), who investigated the textbooks published by SAMT organization including English for the Students of Medicine, in terms of linguistic input, linguistic output, and their relationship to each other concerning the applied methodology, reported that the textbooks lack one integrated approach and lesson plan. He adds that the textbooks do not follow any specific purpose regarding the selected reading passages, or activities designed for improving the learners' translation or comprehension ability.

The study also intended to investigate the incorporation of language skills in the textbooks. The results showed that there has been a focus on vocabulary in the commonly used books in the universities. The reading skill was the second most frequently covered skill in the GE textbooks used in the Iranian medical universities which was followed by the speaking skill. Speaking was also dealt with narrowly in two of the three commonly used textbooks in the form of answering the questions orally after reading a passage. They are not dialogic or conversational. They require the students to answer the questions after studying the reading comprehension passage in the book. Grammar, pronunciation, and writing were sparsely covered in the books, and listening skill was not covered in any of them. The findings show that vocabulary and reading have been overemphasized at the expense of other language skills.

Similarly, Nezakatgoo and Behzadpoor (2017) explored the main challenges of teaching English in medical universities of Iran, arguing that the courses are dominated by the systematic study of grammar and the regular carrying out of translation exercises into and out of Persian. They also believed that reading and learning technical vocabularies are emphasized but the ability to write and speak has remained largely unnoticed. They maintained that the content of the courses should cover learners' target language use situations tasks and what they would do through the language after graduation from the university.

Weisi and Ashrafabadi (2018), who investigated students' perspectives on, and their future needs for, English courses offered at Kermanshah University of Medical Sciences in the west of Iran, reported that most students consider all the skills and sub-skills of utmost significance for their success in their current and future careers. They also complained about the English courses offered at the university and considered no or very few matches between the English courses offered and students' future needs. They conclude that curriculum designers should revise English courses based on the required and specified needs of the students and that pedagogical materials be selected accordingly. Shomoossi Rad et al. (2013) note that the English courses offered at Iranian medical universities are disorganized, adding that the General English courses encourage the students to focus on reading comprehension, literal translation, lexical equivalence, and simple exercises in English. They complain that the English teaching course books are diverse in the market, and instructors are not normally given clear instructions and training on methods of teaching and lesson plans. They conclude that a feeling of inefficiency will remain as long as the revision of English language teaching curriculum is ignored. Likewise, Gholaminejad (2020) investigated the present and target situation academic language needs of Iranian undergraduate students of social and natural sciences at Sharif University of Technology and Shahid Beheshti University, suggesting that the English language program at the universities should be revised.

\section{Conclusion}

The present study aimed to identify the GE textbooks used at medical universities in the Iranian context and to investigate the incorporation of different language skills in the textbooks. The study discovered that different universities used different textbooks and even in the same university, colleges used different textbooks. The universities differed in the number of and type of the textbooks they used. Some universities used only one textbook, while others used many. Moreover, some universities used medically oriented general English textbooks, some employed non-medically oriented general English textbooks, and some used a combination of medically and nonmedically oriented textbooks. It was, however, noticed that a number of the textbooks were more commonly used in the universities. The existing differences which are largely due to the lack of a unified curriculum for GE in the Iranian ministry of health, treatment, and education drive universities to adopt resources based on their individual preferences and evaluations. The differences can lead to disparity in the quality of teaching and information the students receive, which in turn, can harm educational justice in the institutions. Establishing educational justice should be a primary goal of educational systems as education is the most common asset available to the general public (Khan, 2012). Moreover, it was discovered that the identified textbooks did not cover all language skills and contained more reading and vocabulary skills. Additionally, most researchers have blamed the textbooks commonly in medical universities for a lack of standards. The study concludes that the development of a nationwide GE curriculum that is based on the present and future needs of the students can contribute to harmonizing GE materials, organize GE teaching, and exercise educational justice in the universities. Given the existing lacks and disparities, the study suggests that GE 
textbooks meeting the medical sciences students' needs for language skills be developed and introduced to all medical education universities across the country in a unified national GE curriculum.

\section{References}

Ackert, P. (1998). Concepts and comments. https://www.goodreads.com/book/show/2497952.Concepts_Comments

Ahmadi, A., \& Derakhshan, A. (2016). EFL teachers' perceptions towards textbook evaluation. Theory and Practice in Language Studies, 6(2), 260-267. doi: 10.17507/tpls.0602.06

Akbari, O., \& Pourabbas, H. (2015). Evaluation of Iranian second-grade high school English textbook based on needs analysis approach. Journal of Applied Linguistics and Language Research, 2(5), 19-34. http://www.jallr.com/index.php/JALLR/article/view/89

Al Harbi, A. A. M. (2017). Evaluation study for secondary stage EFL textbook: EFL teachers' perspectives. English Language Teaching, 10(3), 26-39. doi:10.5539/elt.v10n3p26

Alum, V. (2012). English for medical purposes: Doctors. lulu.com https://www.amazon.com/English-MedicalPurposes-Virginia-Allum/dp/1471678628

Atai, M. R., Shoja, J., Kafshgarsouteh, M., \& Zolghadri, M. (2013). English for the students of medicine. Tehran: SAMT.

Bradshaw, C., Atkinson, S., \& Doody, O. (2017). Employing a qualitative description approach in health care research. Glob Qual Nurs Res, 24(4). doi: 10.1177/2333393617742282

Cohen, B. J., \& Depetris, A. (2013). Medical terminology: An illustrated guide. Jones \& Bartlett Learning; Illustrated edition.

Crawford, T., \& Candlin, S. (2013). A literature review of the language needs of nursing students who have English as a second/other language and the effectiveness of English language support programmes. Nurse Education in Practice, 13(3), 181-185. doi: 10.1016/j.nepr.2012.09.008

Day, D. R., Yamanaka, J., Harsch, K., \& Ono, L. (2008). Cover to cover: reading comprehension and fluency. New York, NY: Oxford University Press.

Deedari, R., \& Zia Hosseini, M. (1997). English for the students of medicine.Tehran: The Center for Studying and Compiling University books in Humanities, SAMT.

DehGhaedi, M. (2013). Lexical analysis of general English textbook in Iranian universities. International Journal of Language Learning and Applied Linguistics World, 4(2), 15-24.

Ebadi, S., \& Naderifarjad, Z. (2015). Evaluation of EAP textbooks: A comparison between SAMT English for medical students and Oxford English for career. Journal of Applied Linguistics and Language Research, 2(3), 133-149. http://www.jallr.com/index.php/JALLR/article/view/48

Farhady, H. (1398). General English. SAMT.

Fitzgerald, P., McCullagh, M., \& Wright, R. (2010). English for medicine in higher education studies course book with downloadable audio. GARNET EDUCATION. https://nyelvkonyvbolt.hu/en/shop/books-for-languagelearning/vocational-language/medical/english-for-medicine-in-higher-education-studies-course-book-withdownloadable-audio

Genesee, F., \& Upshur, J. A. (1996). Classroom-based evaluation in second language education. Cambridge University Press.

Glendenning, E. H., \& Holmstrom, B. (2005). English in medicine: A course in communication skills. Cambridge University Press.

Glendinning, E. H., \& Howard, R. (2007). Professional English in use: Medicine. Cambridge.

Gholaminejad, R. (2020). What do Iranian undergraduate students of social vs. natural sciences say about their language needs? International Journal of Research in English Education (IJREE), 5(1), 104-115. http://ijreeonline.com/article-1-279-en.html 
Gyorffy, M. (2005). English for doctors. http://versatile4u.blogfa.com/post/875

Hull, M. (2009). Medical English clear \& simple: A practice-based approach to English for ESL healthcare professionals. F. A. Davis Company.

Jalali, M. (2011). Evaluation of an EFL English course-book. The Iranian EFL Journal, 1(1), 71-88.

Karami, Y., \& Lohran Poor, M. (2020). A comparative corpus-based analysis of using hedging, boostering, and selfmentioning metadiscourse markers in Persian and English psychology books. International Journal of Research in English Education (IJREE), 5(2), 13-28. http://ijreeonline.com/article-1-275-en.html

Khan, A. S. (2012). Equity or equality in medical education. J Educeval Health Prof, 9(3), 1. doi: 10.3352/jeehp.2012.9.3

Maleki, A., \& Kazemi, M. (2012). The evaluation and comparison of two most widely used textbooks for teaching English to the Iranian students of medicine. The Iranian EFL Journal, 8(3), 70-93.

McCarthy, M., \& O’Dell, F. (2005). English collocations in use. Cambridge: Cambridge University Press.

McCullagh, M., \& Wright, R. (2008). Good practice: Communication skills in English for medical practitioners. Cambridge University Press.

Milosavljević, N. (2008). Interrelationship between learning English language and students' medical education. Srpski arhiv za celokupno lekarstvo, 136(7-8), 441-444. https://pubmed.ncbi.nlm.nih.gov/18959184

Milosavljević, N., \& Bakić, M. (2008). The cohesive role of foreign language in students' adoption of medical knowledge-conjunction of classical learning and web-based learning. Acta Medica Medianae, 47(1), 32-36. https://www.researchgate.net/publication/26605005_The_cohesive_role_of_foreign_language_in_students_ado ption_of_medical_knowledge-conjunction_of_classical_learning_and_web-based_learning

Mirhassani, S. A., \& Farhadi, H. (1382). Reading through interaction. Tehran: Zabankade

Nejati, R., \& Cheraghi, Z., \& Nasery, N. (2018).Evaluation of tokens of communicative language teaching in prospect (1) of Junior high school in Iran. Journal of Technology of Education, 13(1), 41-53. https://www.sid.ir/en/journal/ViewPaper.aspx?ID=671304

Nezakatgoo, B., \& Behzadpoor, F. (2017). Challenges in teaching ESP at medical universities of Iran from ESP stakeholders' perspectives. Iranian Journal of Applied Language Studies, 9(2), 59-82.

Nili Ahmad Abadi, M., \& Dana, A. (2017). A query on the components and aspects of critical assessment of academic textbooks with an emphasis on the principles of planning and organizing educational messages. Critical Studies in Texts \& Programs of Human Sciences, $219-233$. http://criticalstudy.ihcs.ac.ir/article_2926.html?lang=en

Norouzzadeh, R., \& Kossary, M. (2010). Description of the characteristics of the quadruplet elements undergraduate curriculum with emphasis on training entrepreneurship skills. Quarterly Journal of Research and Planning in Higher Education, 15(4), 1-18. http://journal.irphe.ac.ir/article-1-672-en.html

Pournia, Y. (2019). Current English language references do not satisfy medical students' needs: A study on the vocabulary of the English language references and questions in the comprehensive examination of basic medical sciences in Iran. Journal of Medical Education Development, 12(35), 55-61. http://zums.ac.ir/edujournal/article1-1119-en.html

Rahmanian, E., Hosseini, Y., \& Haghbeen, M. (2017). Exploring the level of compliance with educational justice among the students of Jahrom University of Medical Sciences in 2014: A descriptive-analytic study. International Journal of Scientific Study, 5(4), 398-401. doi: 10.17354/ijssI/2017/54

Razmjoo, S. A., \& Raissi, R. (2010). Evaluation of SAMT ESP textbooks for the students of medical sciences. Asian ESP Journal, 6(2), 107-149.

Ribes, R., \& Ros, P. R. (2005). Medical English. Springer. https://www.amazon.com/Medical-EnglishRam\%C3\%B3n-Ribes/dp/3540254285 
Saharkhiz Arabani, A., Fathi, J., \& Balalaei Somehsaraei, R. (2019). The effect of use of native-accent and non-native accent materials on the Iranian EFL learners' listening comprehension: An EIL perspective. International Journal of Research in English Education (IJREE), 4(3), 42-54. http://ijreeonline.com/article-1-207-en.html

Sahragard, R., \& Rahimi, S. A. (2018). Textbook evaluation of family and friends series based on teachers' perspectives. Journal of Applied Linguistics and Language Research, 5(2), 68-85. https://www.researchgate.net/publication/338459754_Textbook_Evaluation_of_Family_and_Friends_Series_B ased_on_Teachers\%27_Perspectives

Shomoossi, N., Rad, M., \& Rakhshani, M. (2013). Efficacy of English language programs as judged by nurses and students of nursing: Do nurses in Iran need to know English? Acta Facultatis Medicae Naissensis, 30(3), 137143. doi: 10.2478/afmnai-2013-0005

Slatte, P. (2006). Curriculum development in the postmodern era. New York: Routledge.

Tahririan, M. H., \& Ameri-Golestan, M. A. (2011). English for students of medicine. SAMT.

Tahririan, M. H., \& Mehrabi, F. (1994). English for the students of medicine. Tehran: SAMT Publications.

Tajeddin, Z. (2005). English for business communication. First National ESP/EAP Conference, Tehran, Iran.

Weisi, H., \& Ashrafabadi, F. (2018). Do English courses offered at Kermanshah university of medical sciences fulfill students future needs? Educational Research in Medical Sciences, 7(1). doi: 10.5812/erms.81403

Zwier, L. J. (2011). Inside reading: the academic word list in context. Oxford University Press. 